\title{
A Expansão Cafeeira e a Modernização da Economia Brasileira.
}

\section{Maria da Guia Santos Garels *}

\section{1 - A expansão cafeeira e a industrialização}

No Brasil, a agricultura para exportaçăo foi responsável pelo excedente econômico e consequentemente pelo desenvolvimento urbano e industrial após a segunda metade do século XIX. No periodo de 1820 a 1940 , oito produtos agrícolas foram responsáveis pela quase totalidade do valor das exportaçðes, embora após 1840 o café tenha se tornado o principal produto do Brasil no mercado mundial.

A partir de 1850, notamos um grande desenvolvimento do setor de exportaçăo, o qual consegue dobrar seu volume de exportaçăo per capita em cerca de 50 anos. É também a partir dessa data que surgem grandes transformaçóes na situaçăo agricola do país. Essas mudanças estiveram associadas ao declínio agrícola do Norte/Nordeste e à ascensão da atividade agrícola do Sudeste, através, sobretudo, da cafeeicultura.

A agricultura do café no Brasil existe desde as primeiras décadas do século XVIII, mas somente após 1810 a produçăo de café

") Professora do Departamento de História e Geografia, da Universidade Federal da Paraiba, Campus II - Campina Grande, Doutora pela Universidade de Nüremberg.

\begin{tabular}{|l|l|l|l|l|l|}
\hline Rev. Raízes & Campina Grande & Ano X & $N^{9} 8$ & p.89-111 & jan.-dez./1991 \\
\hline
\end{tabular} 
começa a ter grande expansáo, especialmente após 1870, com o surto cafeeiro no planalto piratiningano/Săo Paulo.

\section{TABELA 1.}

Comércio exterior do Brasil - principais produtos. (\% sobre o total da exportaçăo)

\begin{tabular}{|r|r|r|r|r|r|r|r|r|}
\hline Decénios & café & açúcar & cacau & $\begin{array}{r}\text { erva } \\
\text {-mate }\end{array}$ & fumo & algodăo & $\begin{array}{r}\text { bor- } \\
\text { racha }\end{array}$ & $\begin{array}{r}\text { couros } \\
\text { peles }\end{array}$ \\
\hline $1821-30$ & 18,4 & 30,1 & 0,5 & - & 2,5 & 20,6 & 0,1 & 13,6 \\
$1831-40$ & 43,8 & 24,0 & 0,6 & 0,5 & 1,9 & 10,8 & 0,3 & 7,9 \\
$1841-50$ & 41,4 & 26,7 & 1,0 & 0,9 & 1,8 & 7,5 & 0,4 & 8,5 \\
$1851-60$ & 48,8 & 21,2 & 1,0 & 1,6 & 2,6 & 6,2 & 2,3 & 7,2 \\
$1861-70$ & 45,5 & 12,3 & 0,9 & 1,2 & 3,0 & 18,3 & 3,1 & 6,0 \\
$1871-80$ & 56,6 & 11,8 & 1,2 & 1,5 & 3,4 & 9,5 & 5,5 & 5,6 \\
$1881-90$ & 61,5 & 9,9 & 1,6 & 1,2 & 2,7 & 4,2 & 8,0 & 3,2 \\
$1891-00$ & 64,5 & 6,0 & 1,5 & 1,3 & 2,2 & 2,7 & 15,0 & 2,4 \\
$1901-10$ & 51,3 & 1,2 & 2,8 & 2,9 & 2,4 & 2,1 & 28,2 & 4,3 \\
$1911-20$ & 53,0 & 3,0 & 3,6 & 3,0 & 2,6 & 2,0 & 12,1 & 6,2 \\
$1921-30$ & 69,6 & 1,4 & 3,2 & 2,7 & 2,1 & 2,4 & 2,6 & 4,6 \\
$1931-40$ & 52,4 & 0,4 & 4,1 & 1,7 & 1,6 & 13,9 & 1,0 & 4,4 \\
\hline
\end{tabular}

Fonte: Anuárlo Estatistico do Brasil, 1939, IBGE, Aio de Janeiro, p. 1380.

Após 1840, a produçăo brasileira de café passa a ter uma crescente participaçăo no consumo mundial de café. Vários fatores contribuiram para o desenvolvimento do café no Brasil, entre eles, podemos destacar:

a) o aumento da demanda mundial para o produto;

b) o colapso da economia de mineraçăo em Minas, que liberou a máo-de-obra para a pecuária e para a agricultura;

c) a adaptaçăo que a cultura do café teve na regiăo Sudeste, especialmente em São Paulo, a partir da segunda metade do século XIX; 
d) o estímulo que a familia real portuguesa no Brasil dá ao plantio e consumo de café. O grande aumento da produção de café também surgiu vinculado à especializaçăo das unidades produtoras, isto é, das fazendas. ${ }^{1}$

\section{TABELA 2.}

Contribuição do Brasil na produção de café.

\begin{tabular}{|cc|}
\hline Período & \% da produçăo mundial \\
\hline $1820-29$ & 18,8 \\
$1830-39$ & 29,7 \\
$1840-49$ & 40,0 \\
$1850-59$ & 52,1 \\
$1860-69$ & 49,7 \\
$1870-79$ & 49,1 \\
$1880-89$ & 56,6 \\
$1890-94$ & 59,7 \\
$1895-99$ & 66,7 \\
$1900-04$ & 75,6 \\
\hline
\end{tabular}

Fonte: Hans Scherer. "Die Kaffeevalorisation und Valorisationsversuche in anderen Welthandelsartikeln", in: Weltwirtschaftiches Archiv, vol. 14, Jena 1919, p. 336.

Na segunda metade do século $X I X$, sobreludo a partir das décadas de 1860 e 1870 , a produção cafeeira passou por grandes mudanças. O processo dessas transformaçōes é a história da formação de novas relações de produção não só na economia cafeeira mas no conjunto da sociedade brasileira. O desenvolvimento da economia cafeeira permitiu que houvesse um inicio de

1) TaUnay, Afonso d'Escragnole. História do Café no Brasil, v, 10, Rio de Janeiro 1939.43; BElGUELMAN, Paula A Formação do Povo no Complexo Cafeeiro, $2^{a}$ ed, Sāo Paulo, Pioneira, 1966. 
industrialização auto-sustentável a partir dos anos 1870 e 1880 , no Brasil.

A história econômica brasileira, no período de 1840 a 1914, caracteriza-se pelo desenvolvimento e crise da economia cafeeira; mas essa é também a fase da transformação do trabalho escravo em trabalho assalariado, da expansão do mercado, do crescimento das estradas de ferro e do surgimento das primeiras indústrias.

A passagem para a industrialização é o resultado de um sistema complexo de contradiçóes sociais, existindo um conjunto de lutas econômicas, sociais, políticas e ideológicas.

Assim, para entendermos a globalidade do enredo que envolve o processo de industrialização do Brasil, é necessário considerarmos a industrialização tanto como um processo das forças produtivas, como um processo de produção determinado. Isto significa considerarmos que o desenvolvimento das forças produtivas toma as formas adaptadas à reprodução das relações de produção dominantes.

O desenvolvimento das forças produtivas sob a dominação do capital não é somente desenvolvimento das forças produtivas, é também o desenvolvimento das relações sociais capitalistas. Por conseguinte, todo desenvolvimento de relaçóes de produçăo implica um tipo específico de desenvolvimento das antigas relaçóes de produção.

Sob esse aspecto, a industrialização representa essa transformação do processo de trabalho pelas relaçōes de produção capitalistas. ${ }^{2} \mathrm{~A}$ industrialização cria, portanto, uma ligação entre desenvolvimento técnico e desenvolvimento social. Assim sendo, a industrializaçăo indica a transformação das forças produtivas pelas relações capitalistas, não sendo por conseguinte um processo de desenvolvimento socialmente neutro das forças produtivas.

A industrialização é o estágio final de uma fase mais longa do modo de produção capitalista, ou seja, o período de transição. Inicialmente, o capital subordina o trabalho nas condiçóes técnicas alcançadas pelo processo histórico anterior. Essas condições técnicas implicam a unidade do trabalhador e do meio de trabalho, 
ao nivel do processo de trabalho, enquanto a dominação do capital implica a dissociação do trabalhador e do meio de trabalho. ${ }^{3}$

Vale ressaltar que a transição da subordinação formal à subordinaçăo real do trabalho ao capital não segue um desenvolvimento linear. $O$ desenvolvimento do capitalismo é o resultado de um conjunto de contradiçōes. São essas próprias contradições que vão explicar o processo de criação das condiçб̄es para a industrializaçăo.

A fase de transição do capitalismo no Brasil dá-se quando o capitalismo já é dominante em escala internacional. A dominaçăo nas relações capitalistas em nível mundial significa também a subordinação do capital, em escala nacional, à reprodução internacional do capital. Nos países em que o capitalismo é ainda fracamente desenvolvido, o desenvolvimento do capitalismo apresenta contradiçóes particulares decorrentes da posição subordinada que eles ocupam no conjunto da economia mundial. Todos os obstáculos que os paises em vias de desenvolvimento do capitalismo sofrem, significam uma realidade em face às desigualdades do desenvolvimento das forças produtivas nas diferentes formaçóes sociais. ${ }^{4}$

A economia brasileira, dos meados do século XIX à grande depressão de 1929/30, deve ser analisada levando-se em consideração as caracteristicas especificas do desenvolvimento capitalista no Brasil, uma vez que o pais ocupa uma posiçăo subordinada na economia internacional.

Assim, a partir de 1850 , o capital não se limita mais, a nivel mundial, à troca de produtos, ele se apropria da própria produção a nivel mundial, permitindo assim que o comércio internacional tome um grande crescimento.

Os empréstimos externos efetuados pelo Brasil, embora definam o pagamento do valor do empréstimo, mais o pagamento de juros e comissóes, isto é, pagamento em quantia bem maior do que

3) Ibid., T. II, p. 104.

4) SILVA, Sérglo. Expansão Cafeeira e Origens da Indústria no Brasil, São Paulo, Alfa-Omega, 1976, p. 24. 
recebeu inicialmente, eles desempenham um papel fundamental nas transformaçóes capitalistas da economia cafeeira.

\section{TABELA 3.}

Serviços da dívida externa é novos empréstimos: 1850-1900. (em milhões de mil-réis ou contos)

\begin{tabular}{|ccc|}
\hline Anos & serviço das dividas & novos empréstimos \\
\hline $1850-1860$ & 5,3 & 4,1 \\
$1861-1870$ & 12,0 & 10,1 \\
$1871-1880$ & 16,7 & 9,3 \\
$1881-1890$ & 30,5 & 38,1 \\
$1891-1900$ & 57,3 & 63,3 \\
\hline
\end{tabular}

Fonte: Nelson Werneck Sodré. Formação Histórica do Brasil, São Paulo, Brasiliense, 1963, p. 262.

Esses empréstimos serviram, direla ou indiretamente, para - financiamento da imigração massiva de trabalhadores estrangeiros, e, consequentemente, para a organização de um mercado de trabalho assalariado no Brasil, assim como para a implantação de vários outros serviços públicos e industriais, como: a eletricidade, o gás, os transportes urbanos, etc. e para a consolidação do Estado. ${ }^{5}$

Uma das formas principais de aplicação de capitais estrangeiros são os empréstimos feitos e garantidos pelos governos federal, estadual e até municipal. Em 1913, os ingleses investem no estrangeiro 3.700 milhões de libras, sendo $30 \% \mathrm{em}$ empréstimos a governos, $40 \%$ em títulos de estradas de ferro, $5 \%$ em títulos de empresas de interesse público e $25 \%$ em atividades

5) GRAHAM, Richard. Grä-Bretanha e o Inicio da Modernização no Brasil, São Paulo, Brasiliense, 1973, p. 80; DEAN, Warren. A Industrialização de Săo Paulo, $2^{a}$ ed.. São Paulo, DIFEL, 1971, p. 14 
bancárias, seguros, industriais e atividades extrativas. ${ }^{6}$ Os investimentos diretos săo pequenos, pois os indiretos săo mais garantidos.

\section{TABELA 4.}

Origem, modalidade e valor dos capitais estrangeiros no Brasil, nos anos de 1914 e 1930. (em milhóes de dólares)

\begin{tabular}{|l|rr|rr|}
\cline { 2 - 5 } \multicolumn{1}{c|}{} & \multicolumn{2}{c|}{ Dívida Pública Externa } & \multicolumn{2}{c|}{ Invest. Privados Diretos } \\
\hline Países de origem & 1914 & 1930 & 1914 & 1930 \\
\hline Gră Bretanha & 598 & 860 & 609 & 590 \\
França & 110 & 62 & 391 & 138 \\
Estados Unidos & 5 & 374 & 50 & 194 \\
Outros & 4 & 25 & 146 & 450 \\
\hline Total & 717 & 1.267 & 1.196 & 1.913 \\
\hline
\end{tabular}

Fonte: Flávio A. M. de Saes e Támas Szmrecsányi. "O Capital Estrangeiro no Brasil (1880-1930)", in: Revista Estudos Econômicos, vol. 15, n. 2, 1985, IPE, São Paulo, p. 206.

Sob esse aspecto, o resultado líquido do fluxo de capitais entre os países desenvolvidos e subdesenvolvidos năo é necessariamente desfavorável a esses últimos, embora o pagamento da dívida dos empréstimos represente um maior valor do que o capital adquirido. Apesar do peso da dívida externa, o comércio de exportação e importação, que permitiu o desenvolvimento industrial do Brasil, teria sido mais atingido se năo fossem esses empréstimos. ${ }^{7}$

Como mencionamos a importância das entradas de capitał estrangeiro, é importante associar a importância das saídas desses capitais sob diversas formas e, especialmente, sob a forma de

6) ONODY, Oliver. A Inflação Brasileira' (1820-1958), Rlo de Janeiro, 1960.

7) BOUÇAS, Valentim F. Finanças do Brasil. Divida Externa 18241945, Rio de Janeiro, 1955, vol. XIX. 
serviços de dívida. Levando em consideraçăo o período em seu conjunto, é necessário destacar o peso do serviço da dívida externa, que estrangulava financeiramente o país, apesar dos saldos significativos da balança comercial brasileira (vide a tabela do Anexo 1).

Durante esse período predominaram no Brasil os investimentos britânicos, representando os mesmos mais da metade do total dos investimentos. Os capitais britânicos predominavam da mesma forma em quase todos os países da América Latina até 1914, embora desde os fins do século XIX a Inglaterra comece a perder sua posição no global dos investimentos estrangeiros no mercado brasileiro. Os capitais ingleses dirigiram-se, sobreludo, aos setores de mineração, das estradas de ferro, seguros, empréstimos públicos e bancos. ${ }^{8}$

Comparando-se o valor das exportaçóes brasileiras no periodo de 1851-1910, com os investimentos ingleses no Brasil no mesmo periodo, os investimentos britânicos elevaram-se em 1900 cerca de três vezes o valor das exportaçōes e mais de dois terços do produto interno líquido. ${ }^{9}$

O café, após 1840 , tornou-se o motor do desenvolvimento capitalista no Brasil devido ao fluxo de capilais que a economia cafeeira iria gerar no conjunto da economia e, em particular, nas regióes onde o plantio do café solidifica-se.

Uma das características do processo de industrialização do Brasil parece ser o fato de ela surgir como subjacente às atividades exportadoras. É a partir do último decênio do século XIX que a indústria brasileira encontra meios favoráveis a sua expansão. De um modo gẹral, contribuíram para esse processo a aboliçăo do trabalho escravo, a expansão da economia cafeeira e da borracha, a grande imigração estrangeira, a política governamental em favor da indústria nacional e o fluxo de capitais estrangeiros; contudo, é o capital cafeeiro que mais contribuiu para o surgimento $e$ fortalecimento da indústria no Brasil.

8) CASTRO, Ana Célia. As Empresas Eatrangeiras no Brasil 18601913, Rio de Janelro, Zahar, 1978.

9) BUESCU, Mircea. História Económica do Brasil, Rio de Janeiro, APEC, 1970, p. 284. 
O processo de transformaçăo das plantaçбes de café significa também o processo de formação da burguesia brasileira. A expansăo da economia cafeeira é, portanto, o desenvolvimento do capital cafeeiro. Todavia, a economia e o capital cafeeiros ultrapassam as plantaçóes. A transformaçð̌o das plantaçбos faz parte de um processo mais geral e náo pode ser explicado isoladamente. $O$ aspecto capitalista dessas transformaç6es a o desenvolvimento do capitalismo que tem por base a economia cafeeira, năo podem ser determinados a partir das plantações.

O café foi a base do crescimento industrial do Brasil, sobretudo de São Paulo, porque o comércio deste produto proporcionou a economia monetária. A medida que os fazendeiros encontraram um mercado que pagava em dinheiro seus produtos, cresceu muito o volume de dinheiro em circulaçăo e do crédito bancário. O trabalho assalariado contribuiu para que o uso do dinheiro fosse divulgado pela massa da populaçăo, o que beneficiou o mercado interno. Outros efeitos da circulaçăo do dinheiro deram-se em relaçăo à própria terra, adquirindo ela maior valor comercial. ${ }^{10}$ A terra em Săo Paulo era vendida para obtençăo de capital, ou talvez para a aquisiçåo de máquinas agrícolas ou de açбes de firmas comerciais. ${ }^{11}$

O comércio do café leva os lavradores a interessarem-se mais pelos aspectos comerciais e financeiros de seus negócios. Por isto procuravam eles visitar com mais frequência as cidades a outros se dedicavam às atividades mobiliárias, bancárias, proviam a exportaçăo e a construçăo de estradas de ferro. ${ }^{12} \mathrm{~A}$ medida que a economia cafeeira, e depois a da borracha, se expande, crescem também as casas de exportaçăo, que centralizam toda a produçăo desses produtos. ${ }^{13} \mathrm{~A}$ importância dos capitais aplicados na esiera da economia cafeeira eslá vinculada ao nascimento dos primeiros

10) MONBEIG, Pierre. Pioners el Planteurs de São Paulo, Paris, Armand Colin, 1952, p. 112.

11) DEAN, Warren. A Industrializaçăo de Ss̆o Paulo, ob. cit., p. 32.

12) CANO, Wilson. Raizes da Concentraçăo Industrial om Săo Paulo, Så Paulo, DIFEL, 1977, p. 50; SILVA, Sárglo, ob. cit., p. 56.

13) DEAN, Warren. A Industrislizaço de Săo Paulo, ob. cit., p. 62; MARTINS, Jose de Souza. Empresário - Emprosa na biogralla do Condo Matarazzo, São Paulo, HUCITEC, 1974. 
bancos, uma vez que as operaçбes comerciais exigem o nascimento e a expansăo dos bancos. ${ }^{14}$

A expansão do setor industrial explica-se em parte, também, pelo desenvolvimento da infra-estrutura de transportes, em especial dos ferroviários, que integram nessa fase os mercados regionais e criam a necessidade de novas indústrias de repostos e de consertos. ${ }^{15}$

As linhas de estradas de ferro destinavam-se a levar os produtos de exportaçáo aos portos. Elas também foram utilizadas para intentos da industrializaçăo brasileira, trazendo matériasprimas e combustivel dos portos e do interior, possibilitando a distribuiçăo de bens acabados em diversas áreas do país.

A construção de estradas de ferro na região cafeeira proveio quase toda da acumulaçăo de capitais da atividade cafeeira. ${ }^{16}$

Dessa maneira, o capital cafeeiro possuía diversos aspectos: ele apresenta características do capital agrário, do capital industrial, do capital bancário e do capital comercial. Esses diferentes aspectos explicam as diferentes funçס̄es do capital e, também, com o desenvolvimento do capitalismo, passaram a constituir funçốes relativamente autônomas, preenchidas pelo capital agrário, o capital industrial, etc. ${ }^{17}$

Outro aspecto é a dominaçăo do capital comercial exportador pela posiçăo ocupada, pelo Brasil, no contexto da economia internacional. Devido ao débil desenvolvimento das forças produtivas, o Brasil vê-se designado, na divisão internacional do trabalho, à posiçăo de país exportador de produtos agrícolas. $O$ efeito do desenvolvimento das relaçбes capitalistas mundiais sobre as condiçóes especificas da estrutura econômica brasileira aparece por uma dependência ao mercado internacional. Essa dependência vem reforçar o papel predominante do comércio na economia cafeeira e na totalidade da economia brasileira.

14) DEAN, Warren. A Industrialização de Săo Paulo, ob. cit., p. 60.

15) DEAN, Warren. "A Industriallzação Durante a República Velha", in: História Geral da Civilizaçáo Brasileira, Tomo III, vol 1, 2a ed., Săo Paulo, DIFEL, 1977, pp. 249-307.

16) CANO, Wilson, ob. cit., p. 50; DEAN, Warren. A Industrialização de såo Paulo, ob. cit., p. 63.

17) SILVA, Sérgio, ob. cit., p. 60. 


\section{II - Economia cafeeira e trabalho assalariado}

A extinção definitiva do tráfico de escravos para o Brasil em 1850, embora efetuada sob as pressões políticas e econômicas da Inglaterra, resultou também da situação interna do pais, uma vez que o tráfico de escravos podia ser dispensado como fator de crescimento tanto sob o contexto da conjuntura internacional como nacional. A interrupção do tráfico de escravos criou grande demanda de mão-de-obra nas regiốes cafeeiras em expansão, a qual foi temporariamente resolvida pela relocalização crescente e permanente da força de trabalho escrava do Nordeste para o Sul do Brasil. Impossibilitadas de importar escravos, as lavouras de café que se expandiam, procuram utilizar o braço escravo para as funçóes essenciais, empregando nas tarefas complementares a força de trabalho nativa. Simultâneamente a esta situação, multiplica-se - interesse para introduzir o maior número de imigrantes, para atender às necessidades da grande lavoura cafeeira. Na década de 1850, a produção da grande lavoura de café continuava apoiada fundamentalmente sobre o trabalho escravo. Em 1855, em 2.618 plantações de café na província de São Paulo, havia 55.834 escravos para 6.216 trabalhadores. ${ }^{18}$ A compra de escravos fora das regiões de café não podia manter a mão-de-obra necessária à expansão cafeeira.

Impossibilitados de encontrar a força de trabalho no Brasil, os grandes proprietários de café, especialmente os do oeste paulista, procuraram incentivar a imigraçăo estrangeira. Embora nas regiōes de atividades econômicas tradicionais existisse uma massa de trabalhadores disponivel, as possibilidades de aproveitar essa força de trabalho era limitada. Nas áreas onde predominava o latifúndio, os grandes proprietários conseguiram manter a maior parte dos homens pobres livres vinculados à terra através das relações de trabalho em sistema de agregados, parceiros, volantes, etc., relaçóes que permitiam exclusivamente a auto-subsistência. Apesar desses camponeses não serem proprietários e viverem pobremente, eles permaneceram ligados ao latifúndio, porque ele assegurava a subsistência. Todavia, à medida que ocorre o desenvolvimento da lavoura comercial, os grandes proprietários de terra começam a retomar as terras que os camponeses exploravam para seu próprio sustento. Essa nova realidade leva os 
trabalhadores rurais a deixarem os latifúndios. Mas a falta de uma rede de comuniçăo que interagisse as diferentes regiōes do Brasil e a própria dispersão dos latifúndios, assim como os laços de dependência entre os trabalhadores e os grandes proprietários de terra, reforçam os laços entre os camponeses e o latifúndio ${ }^{19}$.

Dessa maneira, esses trabalhadores, apesar de não disporem de terras e de contarem exclusivamente com sua força de trabalho para sobreviverem, eles não formaram propriamente um mercado de trabalho para as plantações de café.

Várias considerações são importantes quanto à oferta de mão-de-obra no Sudeste. Em contraste com o Nordeste, existia uma grande e crescente demanda de mão-de-obra nas plantaçóes e na produção de café, devido à acentuada vantagem de que desfrutava o Brasil em relação aos demais produtores mundiais de café. $E$ ainda em contraste com o Nordeste, havia demandas crescentes, fora das plantações, pela mão-de-obra local nessa região, provocadas pela demanda itensificada ligada à expansáo da produção de café: ferrovias, rodovias e construçóes portuárias estavam entre as fontes mais importantes dessas demandas. O crescimento urbano se manifestava de forma mais visivel nas áreas do Rio de Janeiro e São Paulo do que no Nordeste, levando com isso a uma outra fonte de demanda de força de trabalho não-escrava nas atividades urbanas. Além do mais, a existência de uma grande área de desbravamento agrícola, especialmente em São Paulo, criou possibilidades de uma agriculíura de subsistência mais satisfatória para os trabalhadores livres, em contraste com o Nordeste, onde a terra para a agricultura de subsistência era mais escassa ${ }^{20}$.

De um modo geral, os fazendeiros tinham uma idéia negativa sobre a força de trabalho não-escrava no Sul, por ser ela menos dócil e mais onerosa do que o escravo. Existia uma grande diferença nas taxas de participaçáo de horas de trabalho entre os nãoescravos e escravos (os não--escravos trabalhavam de sete a nove horas por dia, enquanto os escravos trabalhavam de 14 a 18 horas). Essa grande diferença levava os fazendeiros a considerarem

19) FURTAdo, Celso. Formação Econômica do Brasil, São Paulo, Ed. Nacional, 1970, p. 136.

20) Ibid, p. 136; FRANCO, Maria S. de Carvalho. Homens Livres na Ordem Escravocrata, São Pauto, Ática, 1974, p. 60. 
que a escravidão no Sul fosse mais produtiva do que o trabalho livre. 21

Diante dessas ponderações, podemos considerar que os fazendeiros paulistas não recrutaram mão-de-obra no Nordeste, preferindo recorrer aos imigrantes estrangeiros, porque 0 excedente de mão-de-obra existente no Nordeste não atendia às necessidades da grande lavoura cafeeira; os custos de transporte marítimo intercontinental reduziram-se em fins do século XIX, tornando mais fácil a importação de mão-de-obra da Europa do Sul; as pressōes emigratórias existentes numa ltália superpovoada e estagnada permitiu a criação de uma reserva de força de trabalho livre de quaisquer complicações políticas internas no Brasil. ${ }^{22}$ Finalmente, houve também uma tendência implícita entre os grandes proprietários de café sulistas no sentido de favorecer a măo-de-obra camponesa italiana em detrimento do caboclo do Nordeste, baseada na suposição que este último era menos produtivo. Todos esses fatores proveram o uso de fontes externas, e não internas, de oferta de força de trabalho para a expansăo do café em São Paulo e retardaram as grandes transformaçōes internas de mão-de-obra para um período posterior. ${ }^{23}$

A importação de imigrantes estrangeiros para o Brasil, sobretudo para São Paulo, teve início mesmo antes de ser concretizado o fim do trálico de escravos. Enquanto a produção de café era garantida, năo houve qualquer preocupaçăo quanto à reprodução da força de trabalho escrava, mas, com o fim do tráfico negreiro do Atlântico, começaram a se fazer sentir os problemas do crescimento do estoque de mão-de-obra, conjuntamente à expansăo do café para o Oeste Paulista. ${ }^{24} \mathrm{Com}$ o aumento das plantações e, consequentemente, a maior demanda, a oneraçăo do produlo e a diminuiçăo do lucro, é que a contradição se apresenta, exigindo um meio para superá-la.

As primeiras tentativas de colonizaçăo estrangeira no Brasil foram feitas pelo Senador Vergueiro, que, no periodo de

21) MERRICK, Thomas W. \& Graham, Douglas H. Populaçáo e Desenvolvimento Econômico no Brasil, Rio de Janeiro, Zahar, 1981, p. 116.

22) BEIGUELMAN, Paula., ob. cit., p. 68.

23) Ibidem. Furtado, Celso, ob. cit., p. 139.

24) BEIGUELMAN, Paula., ob. cit., p. 73 
1847 a 1857, estabeleceu em suas plantações 177 famílias alemãs, suiças, belgas e portuguesas. ${ }^{25}$ Não se tratava de migraçăo espontânea, mas sim planejada e financiada pelo próprio plantador. Estas tentativas năo deram resultados devido às relaçóes de trabalho que eram impostas aos colonos. ${ }^{26} \mathrm{~A}$ partir de 1870 , depois de alguns conflitos entre os plantadores de café e as forças mais conservadoras, teve início um movimento de imigração em massa. Os imigrantes, entrados no Brasil após essa data, se dirigiram especialmente para São Paulo, em decorrência da política de subvenção à imigração e da capacidade econômica e financeira existente na região paulista. Mais de $90 \%$ dos imigrantes do Estado de São Paulo nos primeiros anos de República, foram subvencionados. Esse número diminuiu nos períodos seguintes, estabilizando-se em cerca de $40 \%$ até o fim da imigração subvencionada, na década de 1930. Dado o fato da imigração subvencionada estar associada particularmente com o setor cafeeiro de São Paulo, a taxa de imigração não-subvencionada reflete a demanda crescente de trabalho não-agrícola na economia paulista, depois de 1905.27

No periodo de 1880 a 1930 , entraram mais de 4 milhões de imigrantes no Brasil, com cerca de $60 \%$ desse total dirigindo-se para São Paulo.

\footnotetext{
25) CARNEIRO, José Fernando. História da Imigração e Colonização do Brasil, Rio de Janeiro, 1950.

26) COSTA, Emllia Viotti. Da Senzala à Colônia, São Paulo, DIFEL, 1966, p. 86.

27) MERRICK, Thomas W. \& Graham, Douglas H., ob. cit., p. 124.
} 


\section{TABELA 5 .}

Dados escolhidos sobre a migração total e subvencionada para São Paulo - 1882-1929.

\begin{tabular}{|c|c|c|c|}
\hline Período & $\begin{array}{c}\text { Imigração para o Brasil } \\
\text { número }\end{array}$ & $\begin{array}{c}\text { Imigração para São Paulo } \\
\% \text { do Brasil }\end{array}$ & $\begin{array}{c}\% \text { subvencionada } \\
1882-84\end{array}$ \\
\hline $1885-89$ & 319.541 & 14 & - \\
$1890-94$ & 600.735 & 53 & - \\
$1895-99$ & 597.592 & 70 & 91 \\
$1900-04$ & 249.042 & 69 & 93 \\
$1905-09$ & 373.365 & 52 & 51 \\
$1910-14$ & 667.778 & 54 & 39 \\
$1915-19$ & 147.675 & 58 & 41 \\
$1920-24$ & 373.126 & 56 & 45 \\
$1925-29$ & 473.521 & 53 & 34 \\
\hline
\end{tabular}

Fonte: Thomas W. Merick e Douglas H. Graham. População e Desenvolvimento Econômico no Brasil, Rio de Janeiro, Zahar, 1981, p. 125.

A importância dos imigrantes no Brasil não foi só como força de trabalho para a expansão de plantação de café, mas também por sua contribuição como empresários e força de trabalho nas atividades comerciais $\mathrm{e}$ industriais no início do século $X X$. Os imigrantes tiveram grande participação na formação e fortalecimento do setor industrial em Săo Paulo, Santa Catarina, Paraná e Rio Grande do Sul, áreas que mais receberam imigrantes estrangeiros no Brasil. 28

A intensificação da produção, apolada por uma nova estrutura tecnológica de produçăo, passa a demandar mais trabalho. Como esta demanda não pode ser respondida dentro das relaçōes de 
trabalho existentes, necessário se fazia introduzir o trabalho assalariado e, assim, uma nova relação de produção. A manutenção do trabalho escravo constituía, portanto, um obstáculo básico ao desenvolvimento do mercado de trabalho, dai porque a transformação para o trabalho assalariado exige a aboliçăo das relações de produçăo escravistas.

Como, no Brasil, a abolição da escravidão ocorreu de forma lenta e progressiva, ela não só consegue prolongar a manutenção da escravidão, como retarda a passagem ao trabalho assalariado, inclusive e especialmente a transformação dos homens livres e exescravos em trabalhadores assalariados. 29

\section{III - Origens da indústria}

O desenvolvimento da economia cafeeira permitiu que houvesse no Brasil um início de industrialização auto-sustentável após 1870.

Antes dessa época, já existiam alguns estabelecimentos que podiam ser considerados industriais, mas, em geral, eram poucos e pequenos. Em 1850, o Brasil já possuía 72 fábricas - para a manufatura de chapéus, velas, sabão, cerveja, cigarro e tecidos de algodão, das quais 50 estavam localizadas no Rio de Janeiro, dez na Bahia, quatro em Pernambuco, duas no Maranhão e as demais espalhadas por Săo Paulo, Minas Gerais e Rio Grande do Sul. ${ }^{30}$

O importante a observar em relação a essa primeira fase da industrialização é que ela ocorre nos centros urbanos, tendo a tendência de se desenvolver proporcionalmente mais nos centros de maior expressão: Rio de Janeiro, Salvador e Recife. ${ }^{31}$

A partir de 1840, quando se dá o início da grande expansão cafeeira, é que começa no Brasil a montagem de fábricas mais importantes, dotadas de maquinismos mais aperfeiçoados, algumas

29) CONRAD, Robert. Os Últimos Anos da Escravidão no Brasil: 18501888, Rio de Janeiro, Civilizaçāo Brasileira, 1975, p. 162.

30) LIMA, Heitor Ferreira. História Político-Econômica e Industrial do Brasil, Såo Paulo, C.E.N., 1970, p. 264.

31) SIMONSEN, Roberto. A Evolução Industrial do Brasil, Sāo Paulo, Brasillense, 1939, p. 23. 
delas com motor hidráulico ou a vapor e com trabalho dirigido por mestres e contramestres contratados na Europa. ${ }^{32}$

Dessa maneira, a industrializaçăo brasileira vai ensaiar seus primeiros passos a partir desses empreendimentos artesanais urbanos que com o tempo alguns chegam a se transformar em verdadeiras fábricas, começando pela indústria de tecidos de algodăo. Em 1866 existiam no Brasil 9 fábricas de tecidos de algodão; em 1885, $48 .{ }^{33}$

A indústria algodoeira inicialmente vai se concentrar na Bahia e, posteriormente, se desloca para o Centro-Sul. Observa-se, portanto, que seu início se dá justamente numa área onde a agricultura estava em franca estagnação. Esse paradoxo, explica-se pela presença de matéria-prima, fontes de energia, mercados urbanos e rurais. ${ }^{34}$ Salvador contava com um amplo suprimento de algodão, bem como de capital financeiro local e estrangeiro; seu porto facilitava o desembarque de máquinas pesadas; a cidade bem como o interior, contava com uma numerosa populaçåo escrava $e$ uma reserva de mão-de-obra livre para consumir pano grosseiro e, por último, possuía excelentes fontes de energia. ${ }^{35}$ Esses fatores foram responsáveis para que a Bahia mantivesse a liderança da indústria têxtil até fins da década de 1860. A partir dessa época, com o florescimento econômico do Centro-Sul, surgiu um deslocamento do centro têxtil para essa área.

Esse mesmo fato vai ocorrer na região Centro-Sul, uma vez que, com o passar do tempo, a indústria têxtil vai se concentrar dentro da área do Centro-Sul, no grande centro produtor de café, qual seja o Estado de São Paulo. Em início da década de 1880, São Paulo havia ultrapassado Minas Gerais na produção de artigos têxteis. O mesmo irá acontecer com o Distrito Federal. Após 1905, São Pulo deteve a hegemonia da produção de artigos de algodão, ultrapassando o Distrito Federal como maior centro produtor têxtil.

32) DEAN, Warren. A Industrialização Durante a República Velha, ob. cil., p. 261.

33) STEIN, Stanley. Origens e Evolução da Indústria Têxtil no Brasil - 1850/1950, Rio de Janeiro, Ed. Campus, 1979, p. 21; SIMONSEN, Roberto. A Evolução Industrial do Brasil, Săo Paulo, Brasiliense, 1939 , p. 23

34) STEIN, Stanley, ob. cit., p. 35.

$35)$ Ibid., p. 36. 
TABELA 6.

Estabelecimentos industriais arrolados em 1907

\begin{tabular}{|c|c|c|c|c|c|c|c|c|}
\hline \multirow[b]{2}{*}{ Região } & \multicolumn{2}{|c|}{ Estabelecimentos } & \multicolumn{2}{|c|}{ Capital Empregado } & \multicolumn{2}{|c|}{ Operários } & \multicolumn{2}{|c|}{ Valor da Produção } \\
\hline & número & $\%$ & contos & $\%$ & número & $\%$ & contos & $\%$ \\
\hline Centro-Sul & 1.620 & 54,2 & 375.216 & 64,6 & 78.666 & 57,7 & 409.857 & 61,3 \\
\hline $\begin{array}{l}\text { São Paulo } \\
\text { Distrito Federal }\end{array}$ & $\begin{array}{l}314 \\
652\end{array}$ & $\begin{array}{l}10,5 \\
21,8\end{array}$ & $\begin{array}{l}118.346 \\
168.626\end{array}$ & $\begin{array}{l}20,4 \\
20,0\end{array}$ & $\begin{array}{l}22.355 \\
35.104\end{array}$ & $\begin{array}{l}16,4 \\
25,7\end{array}$ & $\begin{array}{l}110.754 \\
221.620\end{array}$ & $\begin{array}{l}16,7 \\
33,1\end{array}$ \\
\hline Outros Estados & 1.368 & 45,8 & 205.275 & 35,4 & 57.754 & 42,3 & 258.986 & 38,7 \\
\hline Total & 2.988 & 100,0 & 580.691 & 100,0 & 136.420 & 100,0 & 668.843 & 100,0 \\
\hline
\end{tabular}


Como podemos observar, o Centro-Sul detinha $54,2 \%$ dos estabelecimentos industriais fabris, que representavam cerca de $64,6 \%$ do capital empregado no setor manufatureiro. Assim, em 1907, a regiáo que mais se desenvolvera no período anterior, em funçăo do café, era a que detinha a hegemonia da produçăo manufatureira.

Por outro lado, já em 1907, de uma lista de 30 principais produtos de consumo cotidiano (como tecidos de algodåo, gravatas, aniagem, ladrilhos, chapéus, luvas, biscoitos, etc.), a produçăo nacional naquela época supria $78,2 \%$ do mercado nacional. ${ }^{36}$

Entre 1907 e 1920, houve uma grande expansáo na indústria brasileira. Os dados que indicam esse crescimento, de acordo com os próprios autores, têm grande margen de erros, por não terem sido incluídos os pequenos estabelecimentos. Apesar disso, eles demonstram o crescimento industrial do Brasil nas duas primeiras décadas do século XX (vide a tabela do Anexo 2).

Observando-se mais uma vez a distribuição geográfica do setor manufatureiro em 1920, constatamos que nesse ano o CentroSul detinha $55,4 \%$ dos estabelecimentos fabris, sendo os mesmos responsáveis por $67,2 \%$ da produção total desse setor.

Qualquer que seja o critério adotado para fazer a comparaçăo da concentração industrial no Brasil no período de 1,907 e 1920 (número de estabelecimentos, capital empregado ou valor da produção), é dentro do Centro-Sul que sobressai, da comparaçăo entre os dados de 1907 e 1920, a crescente concentração da atividade industrial na área de São Paulo, após 1907.

A industrializaçăo do Brasil, pelo menos até os anos 20 , esteve intimamente relacionada com o desenvolvimento da agricultura. Foi somente com o desenvolvimento da cultura do café no Centro-Sul, especialmente em São Paulo, que se criaram as condiçóes para o início de uma industrializaçăo. Foi o café que possibilitou primeiramente a criação de um mercado para produtos manufaturados. Esse mercado surgiu do resultado de três fatores principais: a elevaçăo da renda per capita no Centro-Sul, uma maior especializaçăo das unidades econômicas e a extensăo, em

36) ALBUQUERQUE, Marcos Cintra C. \& NICOL, Robert. Economia Agricola, Sáo Paulo, McGraw-Hill, 1987, p. 220. 
TABELA 7.

Resultado censitário das indústrias arroladas em 1920

\begin{tabular}{|c|c|c|c|c|c|c|c|c|}
\hline \multirow[b]{2}{*}{ Regiáo } & \multicolumn{2}{|c|}{ Estabelecimentos } & \multicolumn{2}{|c|}{ Capital Empregado } & \multicolumn{2}{|c|}{ Operários } & \multicolumn{2}{|c|}{ Valor da Produção } \\
\hline & número & $\%$ & contos & $\%$ & número & $\%$ & contos & $\%$ \\
\hline Centro-Sul & 7.383 & 55,4 & 1.195 .467 & 65,9 & 175.543 & 63,7 & 2.008 .608 & 67,2 \\
\hline $\begin{array}{l}\text { São Paulo } \\
\text { Distrito Federal }\end{array}$ & $\begin{array}{l}4.145 \\
1.541\end{array}$ & $\begin{array}{l}31,7 \\
11,7\end{array}$ & $\begin{array}{l}537.817 \\
441.669\end{array}$ & $\begin{array}{l}29,6 \\
24,3\end{array}$ & $\begin{array}{l}83.998 \\
56.229\end{array}$ & $\begin{array}{l}30,5 \\
20,4\end{array}$ & $\begin{array}{l}986.110 \\
666.276\end{array}$ & $\begin{array}{l}33,0 \\
22,3\end{array}$ \\
\hline Outros Estados & 5.953 & 44,6 & 619.689 & 34,1 & 99.969 & 36,3 & 980.568 & 32,8 \\
\hline Total & 13.336 & 100,0 & 1.815 .156 & 100,0 & 275.512 & 100,0 & 2.989 .176 & 100,0 \\
\hline
\end{tabular}

Nota: Os dados não incluem nem as salinas nem as usinas açucareiras.

Fonte: Recenseamento do Brasil, 1920, V (pt. 1), p. VIII, IBGE, Rio de Janeiro. 
termos geográficos, do mercado, através da criação de uma infraestrutura ferroviária. Foi o café, ainda, que através da criaçăo de um mercado importador e exportador permitiu o aparecimento de uma estrutura de distribuiçăo para produtos industrializados, sem - qual possivelmente náo teria surgido uma indústria nacional. Além do mais, foi o café - através das correntes migratórias que provocou, especialmente de imigrantes europeus, que estimulou o fluxo de mão-de-obra para a indústria nascente. indiretamente, foi também o café que possibilitou a importação de matérias-primas necessárias à indústria, como por exemplo o carvăo, o trigo, produtos químicos, etc. O café também irá possibilitar a importaçåo de equipamentos sem os quais não poderia ter ocorrido a industrialização. ${ }^{37}$

O capital cafeeiro é o elemento motor para a efetivação das transformaçóes ocorridas no Brasil a partir dos fins do século XIX, porque a economia cafeeira representa o centro de uma rápida acumulação de capital baseada no trabalho assalariado. E é como parte integrante dessa acumulação de capital baseada no trabalho assalariado que nasce a indústria brasileira.

Assim, o café e a indústria representam as novas formas de acumulaçăo capitalista no Brasil, cuja formação se inicia após 1880 , com a rápida acumulação de capital, gerada, sobretudo, com a produção e comércio do café.

37) STEIN, Stanley, ob. cit., p. 26; DEAN, Warren. A Industrializaçăo de São Paulo, ob. cit., p. 36. 


\section{ANEXO 1}

Balança comercial do Brasil - saldos (em contos de réis).

\begin{tabular}{|cr|rr|}
\hline Anos & saldo & Anos & saldo \\
\hline $1851-60$ & 11,6 & 1909 & 423,7 \\
$1861-70$ & 18,9 & 1910 & 225,5 \\
$1871-80$ & 34,3 & 1911 & 210,2 \\
$1881-90$ & 30,9 & 1912 & 168,4 \\
1891 & 25,4 & 1913 & 25,4 \\
1892 & 91,2 & 1914 & 193,9 \\
1893 & 120,7 & 1915 & 459,3 \\
1894 & 80,1 & 1916 & 326,1 \\
1895 & 81,9 & 1917 & 354,4 \\
1896 & 12,1 & 1918 & 147,7 \\
1897 & 92,1 & 1919 & 844,5 \\
1898 & 49,9 & 1920 & 338,2 \\
1899 & 97,1 & 1921 & 19,9 \\
1900 & 301,4 & 1922 & 679,4 \\
1901 & 412,5 & 1923 & $1.029,9$ \\
1902 & 264,8 & 1924 & $1.073,9$ \\
1903 & 256,1 & 1925 & 645,1 \\
1904 & 263,8 & 1926 & 485,0 \\
1905 & 230,5 & 1927 & 371,0 \\
1906 & 300,4 & 1928 & 275,3 \\
1907 & 215,9 & 1929 & 332,7 \\
1908 & 138,5 & & \\
\hline
\end{tabular}

Notas: 1) Para as quatro primeiras décadas, o quadro apresenta saldos anuais médios.

2) Os saldos negativos indicam um excedente das importaçōes sobre as exportações.

Fonte: Nelson Werneck Sodré. Formação Histórica do Brasil, São Paulo, Brasiliense, 1963, p. 262; IBGE. Estatistlcas Históricas do Brasll - 1500 a 1985, Rio de Janeiro, IBGE, 1987, pp. 525-524. 


\section{ANEXO 2}

Resultados gerais dos inquéritos industriais realizados no Brasil em 1907 e 1920.

\begin{tabular}{|l|rr|rr|}
\hline & \multicolumn{3}{|c|}{ Ano } & \multicolumn{2}{c|}{ Aumento } \\
Especificaçáo & 1907 & 1920 & Absoluto & \multicolumn{1}{c|}{ \% } \\
\hline Diversas Indústrias & & & & \\
Número de estabelecimentos & 2.988 & 13.336 & 10.348 & 346,3 \\
Capital empregado (contos) & 580.691 & 1.815 .156 & 1.234 .465 & 212,6 \\
Força motriz (H.P.) & 114.551 & 310.424 & 195.869 & 171,0 \\
Número de operários & 136.420 & 275.512 & 139.092 & 102,0 \\
Valor da prod anual (contos) & 668.843 & 2.989 .176 & 2.320 .333 & 346,9 \\
\hline Usinas Açucareiras & & & & \\
Número de estabelecimentos & 199 & 233 & 34 & 17,1 \\
Capital empregado (contos) & 74.062 & 217.124 & 143.062 & 193,2 \\
Força motriz (H.P.) & 14.066 & 52.872 & 38.806 & 275,9 \\
Número de operários & 13.136 & 18.161 & 5.025 & 38,3 \\
Valor da prod anual (contos) & 67.257 & 211.494 & 144.237 & 214,5 \\
\hline Salinas & & & & \\
Número de estabelecimentos & 53 & 231 & 178 & 335,8 \\
Capital empregado (contos) & 9.461 & 25.400 & 15.939 & 168,5 \\
Força motriz (H.P.) & 510 & 1.640 & 1.130 & 221,6 \\
Número de operários & 2.146 & 3.333 & 1.187 & 55,3 \\
Valor da prod anual (contos) & 3.126 & 23.955 & 20.829 & 666,2 \\
\hline
\end{tabular}

Nota: Foram excluidas de 1907 as oficinas de ótica e fotografia não. recenseadas em 1920.

Fonte: Recenseamento do Brasll, 1920, V (pt. 1), p. V, Rio de Janeiro, IBGE. 


\section{RAIIZES NO 6}

\section{S U MAR IO}

\section{ARTIGOS}

Bruno Lautier: Trabalho assalariado, socialização do trabalhador e estatuto da força de trabalho . . . . . . . . . . . . . . . . . .

Reinaldo Antonio Carcanholo: Crftica à idéia do valor fugaz:a propósito do valor da força de trabatho ...................

Manoel Luiz Małaguti : Marxistas e neoclássicos: uma confrontação metodológica . . . . . . . . . . . . . . . . . . .

Élbio Troccoli Pakman: As conceitualizaçőes do subdesenvolvimento e seus desdobramentos $\ldots \ldots \ldots \ldots \ldots \ldots$

Raimundo Santos: O pequeno investimento como política de desenvolvimento regional: notas sobre as experiências do governo de Allen-

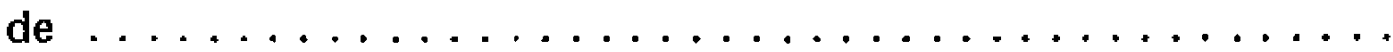

Norma Montalvo de Soler: A agricultura alimentar e o impacto do crédito rural sobre os diferentes tipos de produtos . . . . . . . .

\section{RESENHAS BIBLIOGRÁFICAS}

Nelson Werneck Sodré: Modos de Produção no Brasil (Érico Alberto de A.. Mirandal ........................

Noberto Bobbio: O Conceito de Sociedade Civil (Raimundo Santos). 